\title{
LITERASI SAINS PESERTA DIDIK KELAS V DI MIN TANURAKSAN KEBUMEN
}

\author{
Nur Afni, M. Agung Rokhimawan
}

FITK UIN Sunan Kalijaga Yogyakarta

Email: afninur187@gmail.com,rokhimawan78@gmail.com

\begin{abstract}
ABSTRAK
Hasil survei terbaru Programme for International Student Assesment (PISA) tahun 2015 terhadap kemampuan literasi sains di Indonesia sangat memprihatinkan. Indonesia memperoleh nilai rata-rata skor 493 dan berada di peringkat 62 dari 70 negara anggota. Meskipun demikian, kemampuan literasi sains pada jenjang madrasah ibtidaiyah belum tercakup dalam survey tersebut. Karena itu, artikel ini bertujuan untuk mengungkapkan kemampuan literasi sains peserta didik pada jenjang madrasah ibtidaiyah.

Penelitian dilakukan dengan menggunakan pendekatan kuantitatif non eksperimental dengan metode deskriptif. Teknik pengumpulan data menggunakan instrumen Tes berbentuk soal pilihan ganda yang telah di validasi isi dan konstruk oleh ahli dan validasi empiris keterpakaian menggunakan program Anates $V$-4. Populasinya yakni peserta didik kelas V MIN Tanuraksan. Analisis data yang digunakan yakni dengan statiska deskriptif.

Menurut PISA, literasi sains memiliki tiga dimensi yakni dimensi konteks, dimensi proses dan dimensi sikap. Mengacu pada tiga dimensi tersebut, hasil analisis penelitian ini menunjukkan bahwa kemampuan literasi sains peserta didik MIN Tanuraksan menunjukkan skor dengan kategori tinggi dengan presentase $62,16 \%$.
\end{abstract}

Kata kunci: PISA, Kemampuan Literasi Sains, MIN Tanuraksan Kebumen.

AL-BIDAYAH: Jurnal Pendidikan Dasar Islam

Volume 10, Nomor 01, Juni 2018; P-ISSN: 2085-0034, E-ISSN: 2549-3388 


\section{ABSTRACT}

The results of a recent 2015 Indonesia Program for International Student Assessment (PISA) survey of scientific literacy skills in Indonesia are very alarming. Indonesia scored an average score of 493 and ranked 62 out of 70 member countries. However, the ability of science literacy at madrasah ibtidaiyah level has not been included in the survey. Therefore, this article aims to reveal the ability of science literacy learners at madrasah ibtidaiyah level.

The research was conducted by using non-experimental quantitative approach with descriptive method. Techniques of collecting data using an instrument test in the form of multiple choice questions that have been in the validation of content and constructs by experts and empirical validation of the use of the program use Anates V-4. The population is $5^{\text {th }}$ grade learners in State Islamic Elementary School (State Madrasah Ibtidaiyah) Tanuraksan. Analysis of data used descriptive statistic.

According to PISA, science literacy has three dimensions: context dimension, process dimension and attitude dimension. Referring to the three dimensions, the results of this research analysis indicate that the ability of science literacy learners showed high category scores with a percentage of $62.16 \%$.

\section{Keywords: PISA, the ability of science literacy, State Madrasah Ibtidaiyah Tanuraksan.}

\section{A. PENDAHULUAN}

Abad ke-21 ditandai sebagai abad keterbukaan atau abad globalisasi. Kemendikbud merumuskan bahwa paradigma pembelajaran abad 21 menekankan pada kemampuan peserta didik dalam mencari tahu dari berbagai sumber, merumuskan permasalahan, berpikir analitis dan kerjasama serta berkolaborasi dalam menyelesaikan masalah.

Setiap warga negara pada berbagai jenjang pendidikan perlu memiliki pengetahuan, pemahaman, dan kemampuan yang scientific literate adalah suatu kebutuhan. Peserta didik tidak dapat mencapai performance yang tinggi tanpa bimbingan guru yang terampil dan profesional, waktu belajar yang cukup, ruangan 
gerak, dan sumber belajar di sekelilingnya. ${ }^{1}$ Dijelaskan pula oleh Prayekti dalam Ardianto dan Rubini bahwa ilmu pengetahuan dan teknologi (IPTEK) juga menjadi kunci penting dalam menghadapi tantangan di masa depan. Berbagai tantangan yang muncul diantarannya yaitu berkaitan dengan peningkatan kualitas hidup, pemerataan pembangunan, dan kemampuan untuk menegmbangkan sumber daya manusia. Pendidikan Sains atau IPA sebagai bagian dari pendidikan berperan penting untuk menyiapkan peserta didik yang memiliki literasi sains, yaitu mampu berpikir kritis, kreatif, logis dan berinisiatif dalam menggapai isu di masyarakat yang diakibatkan oleh dampak perkembangan IPA dan teknologi. ${ }^{2}$

Terbentuknya masyarakat yang melek sains (science literate) merupakan salah satu fokus pembangunan masa globalisasi. Pengembangan literasi sains dibangun dengan membudayakan dan meningkatkan kemampuan literasi seperti membaca, menulis, dan berdiskusi. ${ }^{3}$ Literasi sains dianggap sebagai suatu kemampuan dalam pengetahuan sains yang wajib dimiliki oleh peserta didik untuk belajar sains, namun hal tersebut harus didukung dengan kompetensi membaca yang baik oleh peserta didik, karena literasi sains yang disajikan dalam soal literasi sains, memiliki teks fenomena sains yang harus di telaah oleh peserta didik untuk menjawab suatu permasalahan. ${ }^{4}$

Pada era sekarang ini, pesatnya perkembangan ilmu pengetahuan dan teknologi menuntut masyarakat yang berkualitas agar dapat bertahan dan dapat

1. Irfan Hilman and Sud Zakiah Dewi, "Mungkinkah Membangun Literasi Sains di SD/ MI Dengan Kompetensi Guru di Indonesia?," in Membangun Imajinasi dan Kreativitas Anak Melalui Literasi Sains, vol. 2 (Seminar Nasional Pendidikan Dasar SPS UPI, Bandung: Sekolah Pascasarjana Pendidikan Dasar Universitas Pendidikan Indonesia, 2015), 39-44.

2. Didit Ardianto and Bibin Rubini, "Literasi Sains dan Aktivitas Siswa Pada Pembelajaran IPA Terpadu Tipe Shared," Unnes Science Education Journal 5, no. 1 (February 29, 2016): 1168, https://doi.org/10.15294/usej.v5i1.9650.

3. Fuad Jaya Miharja, "Literasi Islam \& Literasi Sains Sebagai Penjamin Mutu Kualitas Manusia Indonesia Di Era Globalisasi," in Prosiding Seminar Nasional II Kerjasama Prodi Pendidikan Biologi Dengan Pusat Studi Lingkungan Dan Kependudukan (PSLK) Universitas Muhammadiyah Malang (Malang: Program Studi Pendidikan Biologi FKIP Universitas Muhammadiyah Malang, 2016), hlm. 1010.

4. Pramita Sylvia Dewi and Diana Rochintaniawati, "Kemampuan Proses Sains Siswa Melalui Pendekatan Saintifik Dalam Pembelajaran IPA Terpadu Pada Tema Global Warming," EDUSAINS 8, no. 1 (June 27, 2016): 22-23, https://doi.org/10.15408/ es.v8i1.1564. 
mengendalikan perkembangan arus globalisasi ke arah yang lebih baik. Kebutuhan akan perkembangan ilmu pendidikan berjalan seiring dengan perkembangan globalisasi. Perkembangan tersebut turut berdampak terhadap pembangunan kualitas masyarakat. Ciri masyarakat yang berkualitas ditunjukkan dengan kemampuan literate meliputi kemampuan berpikir kreatif, menganalisis, mengambil keputusan, bersikap, dan memecahkan masalah berdasarkan pertimbangan informasi ilmiah. Individu yang melek sains dapat menggunakan informasi ilmiah yang dimilikinya untuk mengatasi berbagai masalah yang terjadi dalam kehidupan sehari-hari. Hal inilah yang mendasari pentingnya literasi sains pada era sekarang.

Menurut Uus Toharudin, literasi sains sangat penting untuk dikuasai oleh peserta didik dalam kaitannya dengan cara peserta didik itu dapat memahami lingkungan hidup, kesehatan, ekonomi, dan masalah-masalah lain yang dihadapi oleh masyarakat modern yang sangat bergantung pada teknologi dan kemajuan, serta perkembangan ilmu pengetahuan. ${ }^{5}$ Di dalam dunia pendidikan terdapat 3 kemampuan literate atau literasi yakni literasi bahasa, literasi sains, dan literasi matematika. Fokus penelitian ini ada pada literasi sains. Lietrasi sains memiliki dua kompetensi utama. Pertama, kompetensi belajar sepanjang hayat (lifelong education), termasuk membekali peserta didik untuk belajar di sekolah lanjut. Kedua, kompetensi dalam menggunakan pengetahuan yang dimilikinya untuk memenuhi kebutuhan hidupnya yang banyak dipengaruhi oleh perkembangan sains dan teknologi. ${ }^{6}$

Menurut Fuad Jaya Miharja, tingkat literasi berbanding lurus dengan kualitas pendidikan suatu negara. Indikator mikro tentang tingkat literasi sains manusia dan kualitas pendidikan Indonesia dikaji oleh beberapa studi internasional, seperti The Trends in International Mathematics and Sciennce Study (TIMSS), The Programme for International Student Assesment (PISA), dan Progress in International Reading Literacy Study (PIRLS). ${ }^{7}$ Studi internasional tersebut dapat dijadikan gambaran informasi bagi negara-negara untuk dapat mengembangkan kemampuan literasi.

5. Uus Toharudin, Sri Hendrawati, and H. Andrian Rustaman, Membangun Literasi Sains Peserta Didik (Bandung: Humaniora, 2011), hlm. 3.

6. Ibid.

7. Fuad Jaya Miharja, "Literasi Islam \& Literasi Sains Sebagai Penjamin Mutu Kualitas Manusia Indonesia Di Era Globalisasi," in Prosiding Seminar Nasional II Kerjasama Prodi Pendidikan Biologi Dengan Pusat Studi Lingkungan Dan Kependudukan (PSLK) Universitas Muhammadiyah Malang (Malang: Program Studi Pendidikan Biologi FKIP Universitas Muhammadiyah Malang, 2016), hlm. 1010. 
PISA 2006 yang berfokus pada literasi sains mengukuhkan peserta didik di Firlandia sebagai peserta didik dengan pencapaian tertinggi dalam literasi sains dengan skor rata-rata 563. Kemudian disusul oleh peserta didik dari Hong Kong (542), Kanada (534), Taiwan (532), dan Estonia serta Jepang (531). Dari 57 negara peserta, peserta didik Indonesia mencapai posisi ke-50 dengan skor rata-rata 393. Pada studi sebelumnya, yaitu PISA 2000, peserta didik Indonesia berada pada kelompok bawah dengan nilai rata-rata 395 yang tidak terlalu jauh terpaut dari peserta didik dari negara Brasil (390) dan Tunisia (385). ${ }^{8}$

Hasil penilaian terbaru Programme for International Student Assesment (PISA) tahun 2012 terhadap kemampuan literasi sains Indonesia adalah 375 dari nilai ratarata 494 dan berada di peringkat 63 dari 64 anggota. Dari hasil penilaian tersebut menyatakan bahwa literasi sains peserta didik Indonesia masih rendah. Di lingkup Asia Tenggara (ASEAN) posisi Indonesia masih di belakang Vietnam (411), Thailand (427), dan Malaysia (421). ${ }^{9}$ Hasil penilaian terbaru PISA pada tahun 2015, hasil evaluasi menunjukkan peserta didik di Indonesia mendapatkan skor 403 dari skor rata-rata 493, skor tersebut dirasa masih rendah jika dibandingkan negara Asia yang lainnya, misalnya Jepang 538 dan Singapura 556. Dari 70 negara yang disurvey oleh PISA peringkat literasi sains peserta didik di Indonesia hanya menempati posisi $62 .{ }^{10}$ Kementerian Pendidikan dan Kebudayaan (Kemendikbud) juga merilis pencapaian nilai Programme for International Student Assessment (PISA), Selasa 6 Desember 2016, di Jakarta. Release ini dilakukan bersama dengan 72 negara peserta survei PISA. Hasil survei tahun 2015 yang di release menunjukkan kenaikan pencapaian pendidikan di Indonesia yang signifikan yaitu sebesar 22,1 poin. Hasil tersebut menempatkan Indonesia pada posisi ke empat dalam hal kenaikan pencapaian murid dibanding hasil survei sebelumnya pada tahun 2012, dari 72 negara yang mengikuti tes PISA. Menteri Pendidikan dan Kebudayaan (Mendikbud) Muhadjir Effendy mengungkapkan, peningkatan capaian anak-anak kita patut diapresiasi dan membangkitkan optimisme nasional, tetapi jangan lupa masih banyak PR untuk terus meningkatkan mutu pendidikan karena capaian masih di bawah rerata negara-negara

8. Bahrul Hayat and Sujendra Yusuf, Benchmark Intenational Mutu Pendidika (Jakarta: Bumi Aksara, 2010), hlm. 10-12.

9. Ibid.

10. Hazrul Izwadi, "Sekelumit Dari Hasil PISA 2015 Yang Baru Dirilis,” Desember 2016, http:/www.ubaya.ac.id/2014/content/articles_detail/230/Sekelumit-dari-Hasil-PISA2015-yang-Baru-Dirilis.html. 
OECD. Bila laju peningkatan capaian ini dapat dipertahankan, maka pada tahun 2030 capaian kita akan sama dengan rerata OECD. ${ }^{11}$

National Science Education Standards (NSES) menjelaskan bahwa literasi sains penting, karena: Pertama, pemahaman terhadap sains menawarkan kepuasan pribadi dan memiliki manfaat yang harus dibagi kepada semua orang. Kedua, dalam kehidupan dibutuhkan informasi ilmiah dan cara-cara berpikir ilmiah untuk membuat keputusan. Ketiga, pemahaman terhadap sians bermanfaat dalam pengelolaan alam seperti udara, air, dan hutan. ${ }^{12}$

Jumlah Madrasah Ibtidaiyah (MI) di Indonesia menurut Kementrian Agama Republik Indonesia pada tahun 2016/2017 sebanyak 24.560 lembaga (Madrasah Ibtidaiyah Negeri maupun Madrasah Swasta) dengan jumlah peserta didik sebanyak 3.565.875. ${ }^{13}$ Menurut data yang dilansir Kemenag dari tahun ke tahun mengalami peningkatan jumlah peserta didik maupun lembaga yang berdiri setiap tahunnya. Hal tersebut mendasari peneliti untuk meneliti bagaimana kemampuan literasi sains peserta didik khususnya pada jenjang pendidikan dasar yaitu madrasah ibtidaiyah.

Untuk mengetahui bagaimana kemampuan literasi sains maka perlu diadakan analisis kemampuan peserta didik khususnya di Kebumen dimana peneliti mengambil penelitian. Peneliti memilih MIN Tanuraksan Kebumen sebagai tempat untuk mengambil data. MIN Tanuraksan merupakan madrasah yang peminatnya cukup banyak diantara SD/MI yang ada di Kebumen, memiliki berbagai fasilitas yang memadai dalam pembelajaran yang berbasis agama maupun umum serta memiliki segudang prestasi dalam berbagai bidang yang ada maupun perlombaan-perlombaan yang diadakan oleh berbagai pihak. Terkhusus di bidang IPA/ Sains contoh prestasi yang dipunyai yakni juara 1 dalam Kompetensi Sains Madrasah (KSM) se-Kebumen

11. Biro Komunikasi dan Layanan Masyarakat Kementerian Pendidikan dan Kebudayaan, "Peringkat Dan Capaian PISA Indonesia Mengalami Peningkatan," Desember 2016, https://www.kemdikbud.go.id/main/blog/2016/12/peringkat-dan-capaian-pisaindonesia-mengalami-peningkatan, diunduh tanggal 30 September 2017 pukul 15.00

12. National Research Council, National Science Education Standards (Washington, DC: the National Academy Press, 1996).

13. Direktorat Jenderal Pendidikan Islam Kementerian Agama Republik Indonesia, "Ingin Mengetahui Profil Lembaga Pendidikan Islam?," EMIS, 2016, http://emispendis. kemenag.go.id/emis2016v1/, diunduh tanggal 7 April 2018 pukul 14.00 
2015, juara harapan I Kejuaraan OSN 2017, juara 1 dalam Aksioma 2017 dan lain sebagainya. ${ }^{14}$

Pendidikan sains merupakan sebuah tantangan yang harus dihadapi dan diupayakan sehingga memperoleh kedudukan sejajar dengan seluruh tahapan dalam dunia pendidikan. Pendidikan sains pada tingkat dasar akan dapat memberi kontribusi yang signifikan pada seluruh proses pendidikan anak dan memperkaya hidupnya. ${ }^{15}$ Peneliti memilih level tngkat MI, karena MI merupakan tempat formal pertama kali peserta didik mendapatkan pembelajaran sains. MI mer upakan tahap pendidikan yang tepat bagi peserta didik untuk belajar sains agar memiliki konsep sains yang kuat di usia dini.

Sebagai contoh ketika di MI terdapat bak sampah dengan berbagai warna yang telah disediakan, seperti wana hijau untuk sampah organik dan warna kuning untuk sampah anorganik. Hal tersebut secara tidak langsung mengajarkan konsep sains mengenai pemisahan sampah organik dan anorganik. Hal tersebut akan merangsang peserta didik berfikir ilmiah ketika akan membuang sampah sesuai dengan jenis sampah.

Seperti yang telah disebutkan di atas bahwa literasi sains merupakan kemampuan untuk memahami proses sains dan mendapatkan informasi ilmiah secara bermakna yang tersedia dalam kehidupan sehari-hari. Penilain PISA berorientasi untuk menguji kemampuan peserta didik dalam menggunakan keterampilan dan pengetahuannya untuk menghadapi tantangan kehidupan yang lebih nyata. ${ }^{16}$ Berawal dari fenomena tersebut ada hal yang harus diperbaiki ataupun dirubah dalam pendidikan Sains/ IPA di Indonesia.

Untuk mengetahui bagaimana kemampuan literasi sains maka perlu diadakan analisis kemampuan literasi sains peserta didik di Indonesia, khususnya di Kebumen Jawa Tengah di mana peneliti mengambil data penelitian. Peneliti memilih Madrasah Ibtidaiyah Negeri (MIN) Tanuraksan Kebumen Jawa Tengah sebagai tempat untuk mengambil data.

14. MIN Tanuraksan, "Dokumentasi Prestasi MIN Tanuraksan TA-2015-2017” (Kebumen, Jawa Tengah: MIN Tanuraksan, 2017).

15. R Rohandi, Memberdayakan Anak Melalui Pendidikan Sains- Pendidikan Sains Yang Humanistis (Yogyakarta: Kanisius, 1997), hlm. 116.

16. Uus Toharudin, Sri Hendrawati, and H. Andrian Rustaman, Membangun Literasi Sains ..., 8 . 
Berdasarkan hasil pra riset di kelas V MIN Tanuraksan Kebumen, peneliti menemukan bahwa proses pembelajaran yang dilakukan sudah menggunakan kurikulum 2013. Dimana kurikulum tersebut dapat membangun literasi sains pesera didik. Menurut keterangan Bapak Supriyono selaku wali kelas V MIN Tanuraksan Kebumen pencapain hasil dan proses pembelajran IPA sudah baik. Rata-rata nilai ulangan harian, ataupun nilai ujian tengah semester maupun UAS/UN memiliki rata-rata 8,00 dan masuk katagori baik. Bahkan beberapa siswa maju mewakili MIN Tanuraksan Kebumen dalam beberapa olimpiade IPA. ${ }^{17}$

Dalam penelitian pemilihan kelas $\mathrm{V}$ sebagai populasi dengan alasan peneliti melihat kelas $\mathrm{V}$ sebagai kelas dengan kemmapuan literasi paling tinggi di banding kelas di bawahnya atau kelas 1 hingga 4. Peneliti mengambil seluruh sampel dari kelas VA, VB, dan VC. Dengan adanya paparan yang peneliti sampaikan di atas, maka peneliti tertarik untuk melakukan penelitian dengan judul "Literasi Sains di Kelas V MIN Tanuraksan Kebumen".

\section{B. LANDASAN TEORI}

1. Hakikat Sains

Ciri pendidikan sains adalah bahwa sains lebih dari sekedar kumpulan yang dinamakan fakta. Sedangkan menurut pendapat Sund bahwa sains merupakan kumpulan pengetahuan dan juga kumpulan proses. ${ }^{18}$

2. Konsep dan Prinsip Sains

Sains berasal dari kata science yaitu istilah yang mengacu pada masalahmaslah kealaman (nature). Secara sederhana sains didefinisikan sebagai ilmu pengetahuan yang mempelajari tentang gejala-gejala alam. Sains juga merupakan bagian dari ilmu pengetahuan yang terdiri dari fakta-fakta, konsep-konsep, prisnsip-prisnsip, dan teori-teori yang merupakan produk dari proses ilmiah. Namun demikian sebenarnya sains bukan hanya sebuah produk, melainkan juga proses yang berhubungan dengan sistem, metode atau proses pengamatan, pemahaman dan penjelasan tentang alam. ${ }^{19}$

17. Supriyono, Wawancara dengan Guru Kelas V di MIN Tanuraksan Kebumen, April 16, 2018.

18. Usman Samatowa, Pembelajaran IPA Di Sekolah Dasar (Jakarta: Indels, 2010), hlm. 8-9.

19. Ibid., hlm. 19-20.

54 AL-BIDAYAH, Volume 10, Nomor 01, Juni 2018 


\section{Literasi Sains}

Literasi sains (science literacy), berasal dari gabungan dua kata Latin, yaitu literatus, artinya ditandai dengan huruf, melek huruf, atau berpendidikan dan scientia, yang artinya memiliki pengetahuan. Menurut C.E de Boer dalam Toharudin, dkk., orang yang pertama menggunakan istilah literasi sains adalah Paul de Hart Hurt dari Stanford University. Menurut Hurt dalam Toharudin, dkk., science literacy berarti tindakan memahami sains dan mengaplikasikannya bagi kebutuhan masyarakat. ${ }^{20}$

4. Ruang Lingkup Literasi Sains

Dalam pengukuran literasi sains, PISA menetapkan tiga dimensi besar literasi sains, yakni konten sains, proses sains, dan konteks aplikasi sains. ${ }^{21}$

5. Kemampuan Literasi Sains Peserta Didik Indonesia

Tingkat literasi membaca, matematika, dan sains peserta didik di seluruh dunia dapat diketahui dari tiga studi internasional yang dipercaya sebagai instrumen untuk menguji kompetensi global, yaitu PIRLS, PISA, dan TIMSS.

6. Sains di Sekolah Dasar/ Madrasah

Pembelajaran Sains di sekolah dasar hendaknya dapat memupuk rasa ingin tahu peserta didik secara alamiah. Hal ini akan membantu mereka mengembangkan kemampuan bertanya dan mencari jawaban berdasarkan bukti serta mengembangkan cara berpikir ilmiah. Fokus program pengajaran Sains di sekolah dasar(SD) hendaknya ditujukan untuk memupuk minat dan pengembangan anak didik terhadap dunia mereka di mana mereka hidup. ${ }^{22}$

\section{METODE PENELITIAN}

Pembahasan dalam artikel ini diperoleh dari hasil penelitian dengan pendekatan kuantitatifnon eksperimental dengan metode deskriptif. ${ }^{23}$ Penelitian dilakukan di MIN Model Tanuraksan Kabupaten Kebumen Jawa Tengah yang beralamat di Jl. Cincin

20. Uus Toharudin, Sri Hendrawati, and H. Andrian Rustaman, Membangun Literasi Sains ..., hlm. 1 .

21. OECD, PISA 2015 Result: Student On Line, vol. VI (Perancis: OECD Publishing, 2015).

22. Usman Samatowa, Pembelajaran IPA ..., hlm. 2.

23. Nana Syaodih Sukmadinata, Metode Penelitian Pendidikan (Bandung: Remaja Rosdakarya, 2015), hlm. 53. 
Kota Nomor 354, Gemeksekti, Kebumen. Waktu penelitian adalah pada semester genap pada 17 April 2017-Februari 2018. Populasi, yakni wilayah generalisasi yang terdiri atas obyek atau subyek yang mempunyai kualitas dan karakteristik tertentu yang ditetapkan oleh peneliti untuk dipelajari dan kemudian ditarik kesimpulannya. ${ }^{24}$ Penelitian ini berada di MIN Tanuraksan Kabupaten Kebumen Propinsi Jawa Tengah. Populasi pada peserta didik kelas V berjumlah 70 orang. Sampel yang digunakan dalam penelitian ini menggunakan teknik sampling Nonprobability sampling yaitu samping jenuh dimana peneliti menggunakan seluruh populasi yang ada sebagai sampel. Sampel yang digunakan berjumlah 70 sampel. ${ }^{25}$

Data digali dengan tes berbentuk pilihan ganda. ${ }^{26}$ Instrumen yang digunakan dalam penelitian ini diuji terlebih dahulu validitasnya. Soal tes pilihan ganda literasi sains dilakukan uji validitas isi dan validitas empiris. Uji validitas isi dilakukan dengan mengkonsultasikan kepada dosen pembimbing dan dosen ahli. Analisis data dilakukan dengan menggunakan statistik deskriptif sederhana: menghitung frekuensi dan presentase, yang disajikan dalam bentuk tabel dan grafik. Data hasil penelitian adalah skor kemampuan literasi sains peserta didik kelas V. Skor yang diperoleh masing-masing peserta didik digunakan untuk menghitung skor rata-rata kemampuan literasi sains peserta didik kelas V MIN Model Tanuraksan Kabupaten Kebumen.

\section{HASIL PENELITIAN DAN PEMBAHASAN}

\section{Hasil Penelitian}

a. Validitas

Total soal yang diuji validitasnya sebanyak 35 butir. Adapun hasil uji validitas dengan program Anates V-5 diperoleh hasil seperti disajikan pada Tabel 1.

Tabel 1. Hasil Uji Validitas

\begin{tabular}{lcll}
\hline No. & No. Butir Soal & Korelasi & Keterangan \\
\hline 1. & 1 & 0,116 & - \\
\hline 2. & 2 & 0,158 & - \\
\hline
\end{tabular}

24. Sugiyono, Metode Penelitian Pendidikan (Pendekatan Kuantitatif, Kualitatif Dan R\&D) (Bandung: Alfabeta, 2013), hlm. 117.

25. Ibid., 119.

26. Suharsimi Arikunto, Dasar-Dasar Evaluasi Pendidikan (Edisi Revisi) (Jakarta: Bumi Aksara, 2007), hlm. 9. 


\begin{tabular}{|c|c|c|c|}
\hline 3. & 3 & 0,109 & - \\
\hline 4. & 4 & 0,254 & - \\
\hline 5. & 5 & $-0,006$ & - \\
\hline 6. & 6 & 0,341 & Signifikan \\
\hline 7. & 7 & 0,085 & - \\
\hline 8. & 8 & 0,332 & Signifikan \\
\hline 9. & 9 & 0,397 & Sangat Signifikan \\
\hline 10. & 10 & 0,282 & - \\
\hline 11. & 11 & 0,547 & Sangat Signifikan \\
\hline 12. & 12 & 0,261 & - \\
\hline 13. & 13 & 0,283 & - \\
\hline 14. & 14 & 0,281 & - \\
\hline 15. & 15 & $-0,044$ & - \\
\hline 16. & 16 & 0,329 & Sangat Signifikan \\
\hline 17. & 17 & 0,428 & Sangat Signifikan \\
\hline 18. & 18 & 0,405 & Sangat Signifikan \\
\hline 19. & 19 & 0,178 & - \\
\hline 20. & 20 & 0,424 & Sangat Signifikan \\
\hline 21. & 21 & 0,369 & Sangat Signifikan \\
\hline 22. & 22 & 0,120 & - \\
\hline 23. & 23 & 0,368 & Signifikan \\
\hline 24. & 24 & 0,506 & Sangat Signifikan \\
\hline 25. & 25 & 0,372 & Signifikan \\
\hline 26. & 26 & 0,277 & - \\
\hline 27. & 27 & 0,271 & - \\
\hline 28. & 28 & 0,141 & - \\
\hline 29. & 29 & 0,000 & - \\
\hline 30. & 30 & 0,362 & Signifikan \\
\hline 31. & 31 & 0,369 & Signifikan \\
\hline 32. & 32 & 0,164 & - \\
\hline 33. & 33 & $-0,253$ & - \\
\hline 34. & 34 & $-0,012$ & - \\
\hline 35. & 35 & $-0,042$ & - \\
\hline
\end{tabular}

Berdasarkan tabel di atas hanya 16 soal yang dinyatakan valid karena batas signifikan koefisien korelasi pada program Anates $V-4$ untuk d-f (N-2) 0,001 untuk subyek 70 adalah 0,302 . Soal yang tidak valid peneliti tidak gunakan dalam proses analisis data. 
b. Tabulasi Data

Data skor masing-masing peserta didik yang diperoleh dari tiap butir soal dianalisis untuk memperoleh persentase dan katagori. Pedoman konversi data kuantitatif yang berupa skor menjadi data kualitatif nilai skala lima. Pada penelitian ini mengacu pada rumusan katagori nilai skala lima yang disusun oleh Sukardjo yang telah disajikan dalam bab III. Data persentase dan katagori kemampuan literasi sains peserta didik kelas V MIN Model Tanuraksan yang diperoleh berdasarkan tes disajikan dalam tabel 2 .

Tabel 2. Kemampuan Literasi Sains

\begin{tabular}{lc}
\hline \multicolumn{1}{c}{ Dimensi } & Persentase (\%) Menjawab Benar \\
\hline Konteks & $80,16 \%$ \\
\hline Proses & $54,16 \%$ \\
\hline Sikap & $66,51 \%$ \\
\hline Rata-rata & $62,16 \%$ \\
\hline Kategori & Tinggi \\
\hline
\end{tabular}

Data (yang diperoleh melalui tes) dianalisis kembali untuk ditabulasikan menjadi data keseluruhan kemampuan literasi sains peserta didik di MIN Tanuraksan. Hasil analisis statistik menunjukkan bahwa kemampuan literasi sains peserta didik kelas V MIN Tanuraksan Kabupaten Kebumen secara keseluruhan sebesar $62,16 \%$ dengan kategori tinggi. Persentase tertinggi terdapat pada indikator pertama yaitu sebesar $80,35 \%$ dengan kategori sangat tinggi.

Terdapat tiga tabel yang menunjukkan hasil tersebut, tabel pertama menunjukkan data pengukuran literasi sains dimensi konteks. Indikator pada dimensi ini yakni merujuk pada pengetahuan sains dan pengetahuan tentang sains serta situasi hidup yang melibatkan sains dan teknologi. Ini berarti melihat bagaimana peserta didik menguasai teori sains yang telah didapatkan dan dipelajari. Hasil penelitian tersebut dapat dilihat pada tabel di samping.

Tabel 3. Hasil Penelitian Literasi Sains Dimensi Konten

\begin{tabular}{|c|c|c|c|c|c|c|c|}
\hline \multirow{2}{*}{ Sampel } & \multicolumn{3}{|c|}{ Nomor Soal } & \multirow{2}{*}{$\mathbf{R}$} & \multirow{2}{*}{$\mathbf{N}$} & \multirow{2}{*}{ Skor } & \multirow{2}{*}{ Keterangan } \\
\hline & 8 & 12 & 17 & & & & \\
\hline 1 & 0 & 0 & 1 & 1 & 3 & 33.3 & Sangat Rendah \\
\hline 2 & 1 & 1 & 1 & 3 & 3 & 99.9 & Sangat Tinggi \\
\hline
\end{tabular}


Literasi Sains Peserta Didik Kelas V

\begin{tabular}{|c|c|c|c|c|c|c|c|}
\hline 3 & 1 & 1 & 1 & 3 & 3 & 99.9 & Sangat Tinggi \\
\hline 4 & 0 & 1 & 1 & 2 & 3 & 66.6 & Sedang \\
\hline 5 & 0 & 1 & 0 & 1 & 3 & 33.3 & Sangat Rendah \\
\hline 6 & 1 & 1 & 0 & 1 & 3 & 33.3 & Sangat Rendah \\
\hline 7 & 1 & 1 & 1 & 3 & 3 & 99.9 & Sangat Tinggi \\
\hline 8 & 1 & 0 & 1 & 2 & 3 & 66.6 & Sedang \\
\hline 9 & 1 & 1 & 1 & 3 & 3 & 99.9 & Sangat Tinggi \\
\hline 10 & 1 & 1 & 1 & 3 & 3 & 99.9 & Sangat Tinggi \\
\hline 11 & 1 & 1 & 1 & 3 & 3 & 99.9 & Sangat Tinggi \\
\hline 12 & 0 & 1 & 0 & 1 & 3 & 33.3 & Sangat Rendah \\
\hline 13 & 1 & 1 & 1 & 3 & 3 & 99.9 & Sangat Tinggi \\
\hline 14 & 1 & 1 & 0 & 2 & 3 & 66.6 & Sedang \\
\hline 15 & 1 & 1 & 1 & 3 & 3 & 99.9 & Sangat Tinggi \\
\hline 16 & 0 & 1 & 0 & 1 & 3 & 33.3 & Sangat Rendah \\
\hline 17 & 0 & 1 & 0 & 1 & 3 & 33.3 & Sangat Rendah \\
\hline 18 & 0 & 1 & 0 & 1 & 3 & 33.3 & Sangat Rendah \\
\hline 19 & 1 & 1 & 1 & 3 & 3 & 99.9 & Sangat Tinggi \\
\hline 20 & 1 & 1 & 0 & 2 & 3 & 66.6 & Sedang \\
\hline 21 & 1 & 1 & 0 & 2 & 3 & 66.6 & Sedang \\
\hline 22 & 0 & 1 & 0 & 1 & 3 & 33.3 & Sangat Rendah \\
\hline 23 & 1 & 1 & 1 & 3 & 3 & 99.9 & Sangat Tinggi \\
\hline 24 & 0 & 1 & 1 & 2 & 3 & 66.6 & Sedang \\
\hline 25 & 1 & 1 & 0 & 2 & 3 & 66.6 & Sedang \\
\hline 26 & 0 & 1 & 0 & 1 & 3 & 33.3 & Sangat Rendah \\
\hline 27 & 1 & 1 & 1 & 3 & 3 & 99.9 & Sangat Tinggi \\
\hline 28 & 1 & 0 & 0 & 1 & 3 & 33.3 & Sangat Rendah \\
\hline 29 & 0 & 0 & 0 & 0 & 3 & 0 & Sangat Rendah \\
\hline 30 & 0 & 1 & 0 & 1 & 3 & 33.3 & Sangat Rendah \\
\hline 31 & 0 & 1 & 1 & 2 & 3 & 66.6 & Sedang \\
\hline 32 & 1 & 1 & 1 & 3 & 3 & 99.9 & Sangat Tinggi \\
\hline 33 & 0 & 0 & 0 & 0 & 3 & 0 & Sangat Rendah \\
\hline 34 & 0 & 1 & 0 & 1 & 3 & 33.3 & Sangat Rendah \\
\hline 35 & 0 & 1 & 1 & 2 & 3 & 66.6 & Sedang \\
\hline 36 & 1 & 1 & 0 & 2 & 3 & 66.6 & Sedang \\
\hline 37 & 1 & 0 & 1 & 2 & 3 & 66.6 & Sedang \\
\hline 38 & 0 & 1 & 1 & 2 & 3 & 66.6 & Sedang \\
\hline 39 & 1 & 1 & 0 & 2 & 3 & 66.6 & Sedang \\
\hline 40 & 0 & 1 & 1 & 2 & 3 & 66.6 & Sedang \\
\hline 41 & 1 & 0 & 1 & 2 & 3 & 66.6 & Sedang \\
\hline 42 & 0 & 1 & 1 & 2 & 3 & 66.6 & Sedang \\
\hline
\end{tabular}




\begin{tabular}{|c|c|c|c|c|c|c|c|}
\hline 43 & 0 & 1 & 1 & 2 & 3 & 66.6 & Sedang \\
\hline 44 & 1 & 1 & 1 & 3 & 3 & 99.9 & Sangat Tinggi \\
\hline 45 & 1 & 1 & 1 & 3 & 3 & 99.9 & Sangat Tinggi \\
\hline 46 & 0 & 1 & 1 & 2 & 3 & 66.6 & Sedang \\
\hline 47 & 0 & 1 & 1 & 2 & 3 & 66.6 & Sedang \\
\hline 48 & 1 & 1 & 1 & 3 & 3 & 99.9 & Sangat Tinggi \\
\hline 49 & 1 & 1 & 0 & 2 & 3 & 66.6 & Sedang \\
\hline 50 & 1 & 1 & 1 & 3 & 3 & 99.9 & Sangat Tinggi \\
\hline 51 & 0 & 1 & 1 & 2 & 3 & 66.6 & Sedang \\
\hline 52 & 1 & 1 & 1 & 3 & 3 & 99.9 & Sangat Tinggi \\
\hline 53 & 0 & 1 & 1 & 2 & 3 & 66.6 & Sedang \\
\hline 54 & 0 & 1 & 1 & 2 & 3 & 66.6 & Sedang \\
\hline 55 & 0 & 1 & 1 & 2 & 3 & 66.6 & Sedang \\
\hline 56 & 1 & 1 & 0 & 2 & 3 & 66.6 & Sedang \\
\hline 57 & 0 & 0 & 0 & 0 & 3 & 0 & Sangat Rendah \\
\hline 58 & 1 & 1 & 0 & 2 & 3 & 66.6 & Sedang \\
\hline 59 & 1 & 1 & 1 & 3 & 3 & 99.9 & Sangat Tinggi \\
\hline 60 & 1 & 1 & 1 & 3 & 3 & 99.9 & Sangat Tinggi \\
\hline 61 & 1 & 0 & 1 & 2 & 3 & 66.6 & Sedang \\
\hline 62 & 1 & 1 & 1 & 3 & 3 & 99.9 & Sangat Tinggi \\
\hline 63 & 0 & 1 & 1 & 2 & 3 & 66.6 & Sedang \\
\hline 64 & 1 & 1 & 1 & 3 & 3 & 99.9 & Sangat Tinggi \\
\hline 65 & 0 & 1 & 1 & 2 & 3 & 66.6 & Sedang \\
\hline 66 & 0 & 1 & 0 & 1 & 3 & 33.3 & Sangat Rendah \\
\hline 67 & 0 & 1 & 0 & 1 & 3 & 33.3 & Sangat Rendah \\
\hline 68 & 1 & 0 & 0 & 1 & 3 & 33.3 & Sangat Rendah \\
\hline 69 & 1 & 1 & 1 & 3 & 3 & 99.9 & Sangat Tinggi \\
\hline 70 & 1 & 1 & 1 & 3 & 3 & 99.9 & Sangat Tinggi \\
\hline Total Benar & 40 & 50 & 45 & & & & \\
\hline Persentase & $57,14 \%$ & $71,42 \%$ & $64,28 \%$ & & & & \\
\hline
\end{tabular}

Berdasarkan tabel di atas dapat disimpulkan bahwa peserta didik dengan kategori mendapatkan skor sangat tinggi jika dapat menjawab tiga soal dengan benar pada dimensi konteks literasi sains. Kategori sedang jika peserta didik dapat menjawab dua soal dengan benar, kategori rendah jika peserta didik dapat menjawab satu soal, dan kategori sangat rendah jika peserta didik tidak dapat menjawab soal dengan benar.

Tabel kedua menunjukkan hasil pengukuran literasi sains pada dimensi proses. Terdapat dua indikator dalam dimensi proses, yakni indikator proses 
menggunakan bukti ilmiah berupa kemampuan untuk menafsirkan bukti ilmiah dan menarik kesimpulan, mengidentifikasi asumsi, bukti dan alasan berdasarkan kesimpulan, dan membuat refleksi implikasi sosial dari perkembangan sains dan teknologi.

Indikator kedua yakni indikator proses menjelaskan bukti ilmiah yakni kemampuan untuk mengaplikasikan pengetahuan sains dalam situasi yang diberikan, mendeskripsikan atau menafsirkan fenomena ilmiah dan memprediksi perubahannya. Kemudian mengidentifikasi, deskripsi, eksplanasi dan prediksi yang sesuai. Hasil penelitian pada kedua indikator tersebut dapat dilihat pada tabel di samping.

Tabel 4. Hasil Penelitian Literasi Sains Dimensi Proses

\begin{tabular}{|c|c|c|c|c|c|c|c|c|c|}
\hline \multirow{2}{*}{ Sampel } & \multicolumn{5}{|c|}{ Nomor Soal } & \multirow{2}{*}{$\mathbf{R}$} & \multirow{2}{*}{$\mathbf{N}$} & \multirow{2}{*}{ Skor } & \multirow{2}{*}{ Keterangan } \\
\hline & 9 & 11 & 16 & 22 & 25 & & & & \\
\hline 1 & 0 & 1 & 0 & 0 & 0 & 1 & 5 & 20 & Sangat Rendah \\
\hline 2 & 1 & 0 & 1 & 0 & 0 & 2 & 5 & 40 & Rendah \\
\hline 3 & 1 & 1 & 1 & 0 & 0 & 3 & 5 & 60 & Sedang \\
\hline 4 & 1 & 0 & 0 & 1 & 0 & 2 & 5 & 40 & Rendah \\
\hline 5 & 0 & 1 & 0 & 0 & 0 & 1 & 5 & 20 & Sangat Rendah \\
\hline 6 & 1 & 1 & 0 & 0 & 1 & 3 & 5 & 60 & Sedang \\
\hline 7 & 1 & 1 & 1 & 1 & 1 & 5 & 5 & 100 & Sangat Tinggi \\
\hline 8 & 1 & 0 & 0 & 1 & 0 & 2 & 5 & 40 & Rendah \\
\hline 9 & 1 & 1 & 0 & 0 & 1 & 3 & 5 & 60 & Sedang \\
\hline 10 & 1 & 0 & 0 & 0 & 1 & 2 & 5 & 40 & Rendah \\
\hline 11 & 1 & 0 & 0 & 1 & 1 & 3 & 5 & 60 & Sedang \\
\hline 12 & 1 & 0 & 1 & 1 & 0 & 3 & 5 & 60 & Sedang \\
\hline 13 & 1 & 1 & 1 & 1 & 0 & 4 & 5 & 80 & Tinggi \\
\hline 14 & 1 & 0 & 1 & 1 & 0 & 3 & 5 & 60 & Sedang \\
\hline 15 & 1 & 1 & 0 & 1 & 0 & 3 & 5 & 60 & Sedang \\
\hline 16 & 1 & 1 & 0 & 0 & 1 & 3 & 5 & 60 & Sedang \\
\hline 17 & 1 & 0 & 1 & 0 & 0 & 2 & 5 & 40 & Rendah \\
\hline 18 & 0 & 0 & 0 & 1 & 0 & 1 & 5 & 20 & Sangat Rendah \\
\hline 19 & 1 & 1 & 1 & 1 & 0 & 4 & 5 & 80 & Tinggi \\
\hline 20 & 1 & 1 & 0 & 0 & 1 & 3 & 5 & 60 & Sedang \\
\hline 21 & 1 & 1 & 0 & 1 & 0 & 3 & 5 & 60 & Sedang \\
\hline 22 & 0 & 1 & 0 & 1 & 0 & 2 & 5 & 40 & Rendah \\
\hline 23 & 1 & 1 & 1 & 0 & 1 & 4 & 5 & 80 & Tinggi \\
\hline 24 & 1 & 1 & 0 & 0 & 1 & 3 & 5 & 60 & Sedang \\
\hline 25 & 1 & 1 & 0 & 1 & 0 & 3 & 5 & 60 & Sedang \\
\hline
\end{tabular}




\begin{tabular}{|c|c|c|c|c|c|c|c|c|c|}
\hline 26 & 0 & 0 & 0 & 0 & 1 & 1 & 5 & 20 & Sangat Rendah \\
\hline 27 & 1 & 1 & 1 & 1 & 1 & 5 & 5 & 100 & Sangat Tinggi \\
\hline 28 & 1 & 0 & 0 & 1 & 1 & 3 & 5 & 60 & Sedang \\
\hline 29 & 0 & 0 & 0 & 1 & 0 & 1 & 5 & 20 & Sangat Rendah \\
\hline 30 & 1 & 1 & 1 & 0 & 0 & 3 & 5 & 60 & Sedang \\
\hline 31 & 1 & 1 & 0 & 1 & 0 & 4 & 5 & 80 & Tinggi \\
\hline 32 & 1 & 1 & 0 & 1 & 0 & 2 & 5 & 40 & Rendah \\
\hline 33 & 1 & 1 & 0 & 0 & 1 & 3 & 5 & 60 & Sedang \\
\hline 34 & 0 & 1 & 0 & 0 & 0 & 1 & 5 & 20 & Sangat Rendah \\
\hline 35 & 1 & 1 & 1 & 0 & 1 & 4 & 5 & 80 & Tinggi \\
\hline 36 & 0 & 1 & 1 & 0 & 1 & 3 & 5 & 60 & Sedang \\
\hline 37 & 1 & 1 & 1 & 1 & 0 & 4 & 5 & 80 & Tinggi \\
\hline 38 & 1 & 0 & 0 & 0 & 1 & 2 & 5 & 40 & Rendah \\
\hline 39 & 1 & 1 & 1 & 0 & 1 & 4 & 5 & 80 & Tinggi \\
\hline 40 & 0 & 1 & 1 & 1 & 0 & 3 & 5 & 60 & Sedang \\
\hline 41 & 1 & 1 & 0 & 0 & 1 & 3 & 5 & 60 & Sedang \\
\hline 42 & 1 & 1 & 0 & 0 & 0 & 2 & 5 & 40 & Rendah \\
\hline 43 & 0 & 1 & 0 & 0 & 1 & 2 & 5 & 40 & Rendah \\
\hline 44 & 1 & 1 & 1 & 1 & 0 & 4 & 5 & 80 & Tinggi \\
\hline 45 & 1 & 1 & 0 & 0 & 1 & 3 & 5 & 60 & Sedang \\
\hline 46 & 0 & 1 & 0 & 1 & 0 & 2 & 5 & 40 & Rendah \\
\hline 47 & 0 & 1 & 0 & 0 & 0 & 1 & 5 & 20 & Sangat Rendah \\
\hline 48 & 1 & 1 & 0 & 0 & 1 & 3 & 5 & 60 & Sedang \\
\hline 49 & 1 & 0 & 0 & 0 & 0 & 1 & 5 & 20 & Sangat Rendah \\
\hline 50 & 0 & 0 & 1 & 1 & 0 & 2 & 5 & 40 & Rendah \\
\hline 51 & 1 & 0 & 0 & 0 & 1 & 2 & 5 & 40 & Rendah \\
\hline 52 & 1 & 1 & 1 & 0 & 1 & 4 & 5 & 80 & Tinggi \\
\hline 53 & 1 & 0 & 1 & 0 & 0 & 2 & 5 & 40 & Rendah \\
\hline 54 & 1 & 0 & 1 & 0 & 0 & 2 & 5 & 40 & Rendah \\
\hline 55 & 0 & 1 & 0 & 1 & 1 & 3 & 5 & 60 & Sedang \\
\hline 56 & 1 & 0 & 0 & 1 & 1 & 3 & 5 & 60 & Sedang \\
\hline 57 & 0 & 0 & 0 & 0 & 1 & 1 & 5 & 20 & Sangat Rendah \\
\hline 58 & 0 & 1 & 0 & 0 & 0 & 1 & 5 & 20 & Sangat Rendah \\
\hline 59 & 1 & 1 & 1 & 0 & 0 & 3 & 5 & 60 & Sedang \\
\hline 60 & 1 & 1 & 1 & 0 & 0 & 3 & 5 & 60 & Sedang \\
\hline 61 & 1 & 1 & 0 & 0 & 0 & 2 & 5 & 40 & Rendah \\
\hline 62 & 1 & 0 & 0 & 0 & 1 & 2 & 5 & 40 & Rendah \\
\hline 63 & 1 & 1 & 1 & 0 & 0 & 3 & 5 & 60 & Sedang \\
\hline 64 & 1 & 1 & 1 & 0 & 1 & 4 & 5 & 80 & Tinggi \\
\hline 65 & 1 & 1 & 1 & 1 & 0 & 4 & 5 & 80 & Tinggi \\
\hline
\end{tabular}




\begin{tabular}{|c|c|c|c|c|c|c|c|c|l|}
\hline 66 & 1 & 1 & 1 & 0 & 1 & 4 & 5 & 80 & Tinggi \\
\hline 67 & 1 & 0 & 0 & 0 & 0 & 1 & 5 & 20 & Sangat Rendah \\
\hline 68 & 1 & 1 & 0 & 0 & 1 & 3 & 5 & 60 & Sedang \\
\hline 69 & 1 & 1 & 0 & 0 & 0 & 2 & 5 & 40 & Rendah \\
\hline 70 & 1 & 1 & 1 & 0 & 1 & 4 & 5 & 80 & Tinggi \\
\hline Total Benar & 54 & 46 & 28 & 24 & 30 & & & & \\
\hline Persentase & $77,14 \%$ & $65,71 \%$ & $40 \%$ & $34,28 \%$ & $42,85 \%$ & & & & \\
\hline
\end{tabular}

Berdasarkan tabel di atas dapat disimpulkan bahwa peserta didik dengan kategori mendapatkan skor sangat tinggi jika dapat menjawab empat soal dengan benar pada dimensi proses literasi sains. Katagori tinggi jika peserta didik dapat menjawab tiga soal dengan benar, kategori sedang jika peserta didik dapat menjawab dua soal, dan kategori sangat rendah jika peserta didik menjawab satu soal atau tidak dapat menjawab keseluruhan soal dengan benar.

Tabel ketiga menunjukkan data dari hasil penelitian yakni pengukuran literasi sains pada dimensi sikap. Terdapat dua indikator yakni indikator sikap ketertarikan terhadap sains, yakni kemampuan untuk menunjukkan rasa ingin tahu dalam ilmu pengetahauan dan ilmu yang berhubungan dengan isu-isu. Kemudian, menunjukkan keinginan untuk memperoleh pengetahuan ilmiah dan keterampilan tambahan. Dengan menggunakan berbagai sumber belajar dan metode, menunjukkan kemauan untuk mencari informasi dan memiliki kepentingan yang sedang berlangsung dalam ilmu pengetahuan, termasuk pertimbangan ilmu pengetahuan yang berhubungan dengan karir. ${ }^{27}$

Kedua, yakni indikator sikap mendukung inquiry sains kemampuan untuk menyatakan pentingnya mempertimbangkan perbedaan perspektif sains dan argumen. Kemudian, mendukung penggunaan informasi faktual dan eksplanasi, dan menunjukkan kebutuhan untuk proses logis dan ketelitian dalam menarik kesimpulan. Hasil penelitian dapat dilihat pada tabel di samping.

27. Astri Sutisnawati, "Penerapan Literasi Sains Di Sekolah Dasar," in Membangun Imajinasi Dan Kreativita s Anak Melalui Literasi, vol. 2 (Prosiding Seminar Nasional Pendidikan Dasar SPS UPI, Bandung: Sekolah Pascasarjana Pendidikan Dasar Universitas Pendidikan Indonesia, 2015), hlm. 68-69. 
Tabel 5. Hasil Penelitian Literasi Sains Dimensi Sikap

\begin{tabular}{|c|c|c|c|c|c|c|c|c|}
\hline \multirow{2}{*}{ Sampel } & \multicolumn{4}{|c|}{ Nomor Soal } & \multirow{2}{*}{$\mathbf{R}$} & \multirow{2}{*}{$\mathbf{N}$} & \multirow{2}{*}{ Skor } & \multirow{2}{*}{ Keterangan } \\
\hline & 21 & 24 & 30 & 32 & & & & \\
\hline 1 & 1 & 1 & 1 & 0 & 3 & 4 & 75 & Sedang \\
\hline 2 & 0 & 1 & 1 & 1 & 3 & 4 & 75 & Sedang \\
\hline 3 & 1 & 1 & 1 & 1 & 4 & 4 & 100 & Sangat Tinggi \\
\hline 4 & 1 & 1 & 1 & 0 & 3 & 4 & 75 & Sedang \\
\hline 5 & 0 & 0 & 1 & 0 & 1 & 4 & 25 & Sangat Rendah \\
\hline 6 & 1 & 1 & 1 & 0 & 3 & 4 & 75 & Sedang \\
\hline 7 & 1 & 1 & 1 & 0 & 3 & 4 & 75 & Sedang \\
\hline 8 & 1 & 0 & 0 & 0 & 1 & 4 & 25 & Sangat Rendah \\
\hline 9 & 1 & 1 & 1 & 0 & 3 & 4 & 75 & Sedang \\
\hline 10 & 1 & 0 & 1 & 0 & 2 & 4 & 50 & Sangat Rendah \\
\hline 11 & 1 & 0 & 1 & 0 & 2 & 4 & 50 & Sangat Rendah \\
\hline 12 & 0 & 0 & 1 & 0 & 1 & 4 & 25 & Sangat Rendah \\
\hline 13 & 0 & 0 & 1 & 1 & 2 & 4 & 50 & Sangat Rendah \\
\hline 14 & 0 & 1 & 1 & 0 & 2 & 4 & 50 & Sangat Rendah \\
\hline 15 & 0 & 0 & 1 & 0 & 1 & 4 & 25 & Sangat Rendah \\
\hline 16 & 1 & 0 & 0 & 0 & 1 & 4 & 25 & Sangat Rendah \\
\hline 17 & 1 & 0 & 0 & 0 & 1 & 4 & 25 & Sangat Rendah \\
\hline 18 & 0 & 1 & 0 & 1 & 2 & 4 & 50 & Sangat Rendah \\
\hline 19 & 1 & 1 & 1 & 0 & 3 & 4 & 75 & Sedang \\
\hline 20 & 1 & 1 & 1 & 0 & 3 & 4 & 75 & Sedang \\
\hline 21 & 1 & 0 & 1 & 0 & 2 & 4 & 50 & Sangat Rendah \\
\hline 22 & 0 & 0 & 0 & 0 & 0 & 4 & 0 & Sangat Rendah \\
\hline 23 & 0 & 1 & 1 & 0 & 2 & 4 & 50 & Sangat Rendah \\
\hline 24 & 1 & 0 & 1 & 0 & 2 & 4 & 50 & Sangat Rendah \\
\hline 25 & 1 & 1 & 0 & 0 & 2 & 4 & 50 & Sangat Rendah \\
\hline 26 & 0 & 0 & 0 & 1 & 1 & 4 & 25 & Sangat Rendah \\
\hline 27 & 0 & 1 & 1 & 0 & 2 & 4 & 50 & Sangat Rendah \\
\hline 28 & 1 & 0 & 1 & 0 & 2 & 4 & 50 & Sangat Rendah \\
\hline 29 & 0 & 0 & 1 & 0 & 1 & 4 & 25 & Sangat Rendah \\
\hline 30 & 0 & 1 & 1 & 0 & 2 & 4 & 50 & Sangat Rendah \\
\hline 31 & 1 & 1 & 1 & 0 & 3 & 4 & 75 & Sedang \\
\hline 32 & 1 & 1 & 1 & 0 & 2 & 4 & 50 & Sangat Rendah \\
\hline 33 & 1 & 0 & 1 & 0 & 2 & 4 & 50 & Sangat Rendah \\
\hline 34 & 0 & 1 & 1 & 0 & 2 & 4 & 50 & Sangat Rendah \\
\hline 35 & 1 & 1 & 1 & 0 & 3 & 4 & 75 & Sedang \\
\hline 36 & 1 & 1 & 1 & 0 & 3 & 4 & 75 & Sedang \\
\hline 37 & 0 & 1 & 1 & 0 & 2 & 4 & 50 & Sangat Rendah \\
\hline
\end{tabular}




\begin{tabular}{|c|c|c|c|c|c|c|c|c|}
\hline 38 & 1 & 1 & 1 & 0 & 3 & 4 & 75 & Sedang \\
\hline 39 & 1 & 1 & 1 & 0 & 3 & 4 & 75 & Sedang \\
\hline 40 & 1 & 1 & 1 & 0 & 3 & 4 & 75 & Sedang \\
\hline 41 & 0 & 1 & 1 & 0 & 2 & 4 & 50 & Sedang \\
\hline 42 & 0 & 0 & 1 & 0 & 1 & 4 & 25 & Sangat Rendah \\
\hline 43 & 1 & 1 & 0 & 0 & 2 & 4 & 50 & Sangat Rendah \\
\hline 44 & 1 & 1 & 1 & 0 & 3 & 4 & 75 & Sedang \\
\hline 45 & 0 & 1 & 1 & 0 & 2 & 4 & 50 & Sangat Rendah \\
\hline 46 & 1 & 0 & 1 & 0 & 2 & 4 & 50 & Sangat Rendah \\
\hline 47 & 0 & 0 & 0 & 0 & 0 & 4 & 0 & Sangat Rendah \\
\hline 48 & 1 & 1 & 1 & 0 & 3 & 4 & 75 & Sedang \\
\hline 49 & 0 & 0 & 1 & 0 & 1 & 4 & 25 & Sangat Rendah \\
\hline 50 & 0 & 0 & 1 & 0 & 1 & 4 & 25 & Sangat Rendah \\
\hline 51 & 1 & 1 & 1 & 0 & 3 & 4 & 75 & Sedang \\
\hline 52 & 0 & 1 & 1 & 0 & 2 & 4 & 50 & Sangat Rendah \\
\hline 53 & 0 & 1 & 0 & 0 & 1 & 4 & 25 & Sangat Rendah \\
\hline 54 & 1 & 1 & 1 & 0 & 3 & 4 & 75 & Sedang \\
\hline 55 & 1 & 1 & 1 & 1 & 4 & 4 & 100 & Sangat Tinggi \\
\hline 56 & 0 & 0 & 1 & 0 & 1 & 4 & 25 & Sangat Rendah \\
\hline 57 & 0 & 0 & 1 & 0 & 1 & 4 & 25 & Sangat Rendah \\
\hline 58 & 0 & 1 & 0 & 1 & 2 & 4 & 50 & Sangat Rendah \\
\hline 59 & 1 & 1 & 1 & 0 & 3 & 4 & 75 & Sedang \\
\hline 60 & 0 & 1 & 1 & 0 & 2 & 4 & 50 & Sangat Rendah \\
\hline 61 & 1 & 1 & 0 & 1 & 3 & 4 & 75 & Sedang \\
\hline 62 & 1 & 0 & 1 & 0 & 2 & 4 & 50 & Sangat Rendah \\
\hline 63 & 1 & 0 & 0 & 0 & 1 & 4 & 25 & Sangat Rendah \\
\hline 64 & 1 & 1 & 1 & 0 & 3 & 4 & 75 & Sedang \\
\hline 65 & 1 & 1 & 1 & 0 & 3 & 4 & 75 & Sedang \\
\hline 66 & 1 & 1 & 1 & 0 & 3 & 4 & 75 & Sedang \\
\hline 67 & 0 & 1 & 0 & 1 & 2 & 4 & 50 & Sangat Rendah \\
\hline 68 & 1 & 0 & 1 & 0 & 2 & 4 & 50 & Sangat Rendah \\
\hline 69 & 0 & 1 & 1 & 0 & 2 & 4 & 50 & Sangat Rendah \\
\hline 70 & 1 & 1 & 1 & 0 & 3 & 4 & 75 & Sedang \\
\hline Total Benar & 41 & 44 & 56 & 8 & & & & \\
\hline Persentase & $58,57 \%$ & $62,85 \%$ & $80,00 \%$ & $11,42 \%$ & & & & \\
\hline
\end{tabular}

Berdasarkan tabel di atas, dapat disimpulkan bahwa peserta didik dengan kategori mendapatkan skor sangat tinggi jika dapat menjawab empat soal dengan benar pada dimensi sikap literasi sains. Kategori tinggi jika peserta didik dapat menjawab tiga soal dengan benar. Kategori sedang jika peserta 
didik dapat menjawab dua soal. Dan kategori sangat rendah jika peserta didik menjawab satu soal atau tidak dapat menjawab keseluruhan soal dengan benar.

\section{E. KESIMPULAN}

Berdasarkan hasil analisis dalam penelitian ini dapat ditarik kesimpulan bahwa kemampuan literasi sains peserta didik Kelas V MIN Tanuraksan Kebumen pada dimensi konteks, masuk dalam katagori tinggi dengan persentase 80,35\%. Selanjutnya, pada dimensi proses, masuk dalam kategori sedang dengan persentase 54,16\%, dan dimensi sikap, masuk dalam kategori tinggi dengan persentase 66,51\%. Rata-rata keseluruhan kemampuan literasi sains peserta didik di MIN Tanuraksan Kabupaten Kebumen yaitu 62,16\% dengan kategori tinggi.

\section{F. DAFTAR PUSTAKA}

Ardianto, Didit, and Bibin Rubini. "LITERASI SAINS DAN AKTIVITAS SISWA PADA PEMBELAJARAN IPA TERPADU TIPE SHARED." Unnes Science Education Journal 5, no. 1 (February 29, 2016). https://doi.org/10.15294/ usej.v5i1.9650.

Arikunto, Suharsimi. Dasar-Dasar Evaluasi Pendidikan (Edisi Revisi). Jakarta: Bumi Aksara, 2007.

Biro Komunikasi dan Layanan Masyarakat Kementerian Pendidikan dan Kebudayaan. "Peringkat Dan Capaian PISA Indonesia Mengalami Peningkatan," Desember 2016. https://www.kemdikbud.go.id/main/blog/2016/12/peringkat-dancapaian-pisa-indonesia-mengalami-peningkatan.

Dewi, Pramita Sylvia, and Diana Rochintaniawati. "KEMAMPUAN PROSES SAINS SISWA MELALUI PENDEKATAN SAINTIFIK DALAM PEMBELAJARAN IPA TERPADU PADA TEMA GLOBAL WARMING." EDUSAINS 8, no. 1 (June 27, 2016): 18-26. https://doi.org/10.15408/ es.v8i1.1564.

Direktorat Jenderal Pendidikan Islam Kementerian Agama Republik Indonesia. “Ingin Mengetahui Profil Lembaga Pendidikan Islam?” EMIS, 2016. http:// emispendis.kemenag.go.id/emis2016v1/.

Hayat, Bahrul, and Sujendra Yusuf. Benchmark Intenational Mutu Pendidika. Jakarta: Bumi Aksara, 2010. 
Hilman, Irfan, and Sud Zakiah Dewi. "Mungkinkah Membangun Literasi Sains di SD/MI Dengan Kompetensi Guru di Indonesia?” In Membangun Imajinasi dan Kreativitas Anak Melalui Literasi Sains, 2:39-44. Bandung: Sekolah Pascasarjana Pendidikan Dasar Universitas Pendidikan Indonesia, 2015.

Izwadi, Hazrul. "Sekelumit Dari Hasil PISA 2015 Yang Baru Dirilis," Desember 2016. http://www.ubaya.ac.id/2014/content/articles_detail/230/Sekelumitdari-Hasil-PISA-2015-yang-Baru-Dirilis.html.

Miharja, Fuad Jaya. "Literasi Islam \& Literasi Sains Sebagai Penjamin Mutu Kualitas Manusia Indonesia Di Era Globalisasi." In Prosiding Seminar Nasional II Kerjasama Prodi Pendidikan Biologi Dengan Pusat Studi Lingkungan Dan Kependudukan (PSLK) Universitas Muhammadiyah Malang, 1010-18. Malang: Program Studi Pendidikan Biologi FKIP Universitas Muhammadiyah Malang, 2016.

MIN Tanuraksan. "Dokumentasi Prestasi MIN Tanuraksan TA-2015-2017." Kebumen, Jawa Tengah: MIN Tanuraksan, 2017.

National Research Council. National Science Education Standards. Washington, DC: the National Academy Press, 1996.

OECD. PISA 2015 Result: Student On Line. Vol. VI. Perancis: OECD Publishing, 2015.

Rohandi, R. Memberdayakan Anak Melalui Pendidikan Sains- Pendidikan Sains Yang Humanistis. Yogyakarta: Kanisius, 1997.

Samatowa, Usman. Pembelajaran IPA Di Sekolah Dasar. Jakarta: Indels, 2010.

Sugiyono. Metode Penelitian Pendidikan (Pendekatan Kuantitatif, Kualitatif Dan $R \& D)$. Bandung: Alfabeta, 2013.

Sukmadinata, Nana Syaodih. Metode Penelitian Pendidikan. Bandung: Remaja Rosdakarya, 2015.

Supriyono. Wawancara dengan Guru Kelas V di MIN Tanuraksan Kebumen, April 16, 2018.

Sutisnawati, Astri. "Penerapan Literasi Sains Di Sekolah Dasar." In Membangun Imajinasi Dan Kreativita s Anak Melalui Literasi, 2:67-78. Bandung: Sekolah Pascasarjana Pendidikan Dasar Universitas Pendidikan Indonesia, 2015.

Toharudin, Uus, Sri Hendrawati, and H. Andrian Rustaman. Membangun Literasi Sains Peserta Didik. Bandung: Humaniora, 2011. 
